ent foods used in the diet may produce an undesirable summation of reactions. This small report should prove of very great help to medical officers, administrators and teachers concerned with problems of public health.

\section{High-Level Beach Lines in Morocco}

THE study of the high-level beaches occurring along the North African coast has long occupied quaternary geologists. The term 'high-level' rather than 'raised' is used deliberately as it is believed that they are the result of a rising and falling of the sealevel during interglacial and glacial periods rather than of earth movements. During glacial maxima vast quantities of water were locked up in the form of ice sheets and the level of the sea sank; when the warm conditions of interglacial times supervened the ice melted and the level of the sea rose. High-level beaches, therefore, indicate an interglacial poriod. A number of savants have been concerned with this study and among them must be mentioned M. Georges Choubert, who has contributed an interesting paper (C.R. Acad. Sci., Paris, 245, Sept. 23, 1957) on the correlation between the marine and continental cycles of the Pleistocene period in Morocco. One fact his article shows clearly, and it is a problem which has not yet been satisfactorily explained. The earliest terrace (Sicilian) lios at 90 metres above present sea-level. There was then a fall of the sea with the oncoming of glacial conditions. When the water rose again it only reached 60 metres above present sea-level; and this phenomenon of general lowering continued. As well as the up and down movements of the sea-level, there seems to have been at the sume time a steady depletion of the available sea water. Possibly considerable earth movements caused large underwater deeps which had to be filled, but the explanation of this steady fall in sea-level throughout Pleistocene times, apart from the up and down due to glacial and interglacial phases, is a mystery. The phenomenon is not confined to the Mediterranean. M. Choubert also claims to have discoverod pre-Günz climatic changes beck in the Villafranchian. He equates the latest of these with the pebble culture of Arbaouz. But are any of these so-called early pebble tools really artefacts ? A number of workers have recently come to the conclusion that there are no man-made objects prior to the early Oldoway culture.

\section{Griseofulvin in Horticulture}

Griseofulvin, a new antibiotic, has now been released by the Government for use in horticulture. Trials have shown it to be highly effective in controlling Botrytis (grey mould) in the lettuce crop grown under glass: as a 3 per cent dust, used at approximately $1 \mathrm{oz}$. per $20 \mathrm{sq}$. yd., Botrytis infection was reduced by some 40-50 per cent, treatment both before and after planting-out giving the best control. Application in the form of a 3 per cont atomizing spray was also successful. The cost of the treatment, where the full value of the crop is assessed at $£ 1,500$, would lie between $£ 35$ and $£ 52$, while the gain to the grower is estimated at $£ 190$ per acre. There would also be an increase in size of marketable lettuces from the reduction in infected leaves, and a substantial saving in time and labour spent on trimming. Trials are now in progress on the effect of griseofulvin on other diseases of lettuce, such as downy mildew and damping-off, and will shortly be oxtended to other crops, including strawberries, raspberries and tomatoes. Griseofulvin is not yet available for sale to growers, but the Murphy Chemical Co., Ltd., Wheathampstead, Herts, is marketing a substance, 'Grisovin', containing the antibiotic, and has issued an illustrated leaflet dealing with the control of Botrytis in lettuce under glass with this product. Limited quantities of griseofulvin are available, how. ever, from G. L. Hey at the above address, for research workers in Britain or overseas who are interested in trying the material against species of Botrytis or Mycosphaerella on a range of crops.

\section{Committee of Inquiry into the Fishing Industry}

A Commrtees of Inquiry into the Fishing Industry has recently been formed by the Ministry of Agriculture, Fisheries and Food and the Scottish Home Department "To assess, in relation to developments in fishing and the marketing of fish, the size and pattern, and implications, of an economic fishing industry in the U.K., and to report". Members of the Committee are : Sir Alexander Fleck (chairman), Mr. H. W. Clements, Rear Admiral R. A. Currie, Sir Alister Hardy, Sir Graham Larmor, Mr. I. W. Mac. donald, Mr. George Middleton, Mr. W. B. Reddaway. The secretaries are Miss M. E. Vince, Ministry of Agriculture, Fisheries and Food, and Mr. I. L. Sharp, Scottish Home Department.

\section{Royal Agricultural Society of England Research Medal}

THE Royal Agricultural Society of England offers annually a medal together with an award of one hundred guineas for research work of outstanding merit carried out in the United Kingdom which has proved, or is likely to prove, of benefit to agriculture. Recommendations for this award can be mado by the heads of university departments, research stations and institutes and other research establishments. No direct application by candidates will be considered. Recommendations for the next award must be submitted to the Secretary, Royal Agricultural Society of England, 35 Belgrave Square, London, S.W.1, before January 31, 1958.

\section{Micro- and Semi-Microchemical Methods}

Commencing on January 11, a course of twelve lectures and appropriate practical work will be held on Saturday mornings at the Norwood Technical College from 9.15 a.m. to 12.30 p.m. The course is designed to survey the principal branches of chemistry in which small-scale methods have been successfully applied and is particularly suitablo for teacher's wishing to introduce modern techniques into advanced and scholarship level and degree courses. Further information can be obtained from the Secre. tary, Norwood Tochnical College, London, S.E.27.

\section{University News :}

Bristol

THE following appointments in the University of Bristol have been announced: Dr. D. W. Barritt, as lecturer in medicine; I. W. Cameron, as locturer in dental surgery (prosthetics); Dr. L. C. Frost, as lecturer in genetics in the Department of Botany; N. St. G. Hyslop, as lecturer in clinical veterinary pathology; Dr. P. M. Llewellyn, as lecturer in physics; Barbara M. Q. Weaver, as lecturer in veterinary surgery.

Among the grants, gifts and bequests received by the University are the following : from the Depart- 